\title{
Reflections on the Application of flipped Classroom Teaching Mode in Colleges and Universities
}

\author{
Guijuan $\mathrm{Qu}^{1 \mathrm{a}}$, Shanghong Ding ${ }^{2 \mathrm{~b}}$ and Xiaoqing Dong ${ }^{1 \mathrm{c}}$ \\ ${ }^{1}$ Jilin Agricultural University, College of animal science and technology, China \\ ${ }^{2}$ Jilin Teyan Biotechnological CoLLtd, Changchun 130122 \\ aquguijuan2003@sina.cn, ${ }^{b} 387867001 @ q q . c o m,{ }^{c} d x g 200912 @ 163 . c o m$
}

\begin{abstract}
Keywords: The flipped classroom model; Colleges and Universities; Teaching Quality; Teaching model
\end{abstract}

\begin{abstract}
With the popularization of modern information technology in the field of education and the continuous improvement of teaching idea, the teaching of the classroom has become a hot topic in the education circles both at home and abroad. This paper will summarize the meaning of "flip classroom", the application status in colleges and universities, the conditions of implementation and the challenges they face, and lay the foundation for exploring the application of flip teaching mode in colleges and universities.
\end{abstract}

\section{Introduction}

Since the revolution in science and technology, the application of information technology in the field of education has become more and more extensive. The people's way of life, communication methods and learning methods have taken place in the great change. Under the background of this era, education is undergoing profound changes, in which the change of teaching form has become the focus of attention. As a typical example of the change of teaching form in the information technology era, the teaching of the classroom is accepted and advocated by many educational researchers and practitioners. So what is the flip classroom? What is the current situation of the application of teaching mode in colleges and universities? What are the advantages? What are the conditions of implementation and the challenges? This article will focus on the above several aspects for the inversion of the classroom.

\section{The Meaning of the Flipped Classroom}

Translating the classroom from "Flipped Classroom" or "Inverted Classroom" means reorienting the time inside and outside the classroom and transferring the decision of learning from the teacher to the student. "Let the students at home or outside the classroom to watch the video teacher to explain, and then back to the classroom teachers and students face to face communication and complete the operation of such a teaching form [1].The main teaching process of the classroom is: the teacher will focus on teaching content, difficulties and knowledge points and make a combination of teaching video, students use extra-curricular time to learn the content of the preview, through the teaching video for independent learning process. And through the video learning students can also carry out independent online testing, for inspection and absorb knowledge. And teachers in the classroom can provide more opportunities for students to talk to each other, teachers only as part of the question answering question. This class creates a new model of learning and learning, communication and cooperation, self-thinking and sharing, and soon.

\section{The Application Status in Colleges and Universities}

In recent years, the flip classroom is very popular at home and abroad, "flip classroom" mode, pre-class students use the teacher carefully selected or selected micro-video self-learning, and their learning insights and difficult questions back to the teacher, teacher Answer questions, guide students to practice to consolidate the knowledge learned. As a new type of teaching model has 
been spread to the trend of classroom teaching in colleges and universities [2-4], to improve the teaching of colleges and universities provides a new way. By the impact of the reform of classroom teaching reform, China has also introduced a lot of related theories and cases. Some areas and schools are gradually promoting the practice of reversing the classroom, hoping to try to explore this way to highlight the dominant position of learners, in response to the era of student personality and ability development requirements. At the same time, the rise of $\mathrm{Mu}$ class for college teachers to implement the classroom to provide high quality teaching resources, and indirectly promote the practice of development. Many front-line teachers thus come into contact with the concept of flip classroom, and carry out the practice of flip [5]. Liu Peng in the pathogen biology and immunology training teaching using flip teaching method, the results show that $33 \%$ of the students with outstanding results, no failed students; and the use of traditional teaching methods, only $11 \%$ of the students outstanding results, still $11 \%$ of the students did not pass the examination, indicating that the use of flip classroom teaching effect was significantly better than the traditional method [6]. Long Qian [7] research shows that this new type of teaching model can really improve student achievement, and can improve students' ability of autonomous learning. However, Li Yun et al [8] through the flip classroom teaching model survey analysis found that flip classroom on the student course rate of the effect of the promotion is not obvious. Moreover, the impact on the student's performance is not significant, indicating that there are some limitations in the translation of the classroom. Lu Qiang [9] The results of the survey in the flip classroom show that some students in the classroom learning evaluation and self-evaluation is relatively low, that in the flip of the classroom and not much opportunity to discuss, and almost no valuable statement , $42.2 \%$ of the respondents thought that the questions raised by teachers in general, only $4.7 \%$ of the students that teachers can be very good questions, organize discussion, which to some extent reflects the current renovation of the classroom embarrassment shape.

\section{Flip the Implementation of the Classroom Conditions}

As a new teaching model, the classroom has a greater reliance on the conditions of implementation while re-"shuffling" the traditional classroom structure and its relations. First of all, information technology is the main carrier of the dissemination of knowledge in the classroom, is a prerequisite for reversal of learning. The school provides the necessary conditions for students to provide networking and computer learning. Secondly, the flip classroom advocates "student-centered", but it requires a high level of teacher literacy. Guo et al. [10] in the study shows that teachers must have excellent classroom management and curriculum design capabilities in order to truly create active learning The environment to help students improve their learning ability. This is the basic protection of the smooth and effective implementation of the classroom. Third, flip the classroom to promote student learning style of personalization, training independent collaborative learners, so that students at any time and place with their favorite and customary way to learn. The realization of this goal requires not only students with sufficient time and space resources, but also depends on the students to take the initiative to learn the consciousness and ability. Fourth, the flip classroom emphasizes the continuous improvement of interaction mechanism between teachers and students and the continuous deepening of the interaction level, the excessive number of class students will limit the participation and support of teachers in student group discussions, affecting students' creativity and depth of mind. [11]

\section{Flip the Classroom Challenges and Countermeasures}

As a model of teaching reform in colleges and universities, it is necessary to highlight the advantages that traditional classrooms do not have in the aspects of reconstructing teaching process and realizing personalized teaching by using online and offline class and class teaching methods. In the practice of higher education teaching reform, which play an important role. But as a new thing, in the docking with the traditional teaching, there is a collision in the classroom formalization, knowledge fragmentation, student polarization and other issues worthy of reflection, making the 
new life of the classroom as a landing, which is facing new practical challenges. Turn the classroom to highlight the learner's dominant position, through the use of multimedia technology and other external means to mobilize the learner's sensory system, the birth of the cognitive conflict, stimulate learning motivation, cultivate self -study habit. But the flip of the classroom is not only reflected in the presence of multimedia technology, whether the autonomy of domination, whether the main changes in the relationship between teaching and so on. In response to this situation, we must do the following points in order to really play the advantages of flip classroom. First, for different disciplines, selective applications flip the classroom model. The flip classroom is not applicable to all disciplines, and a large number of studies have found that it is more suitable for comprehensive practical disciplines. The teaching results of the conceptual principles of colleges and universities are not satisfactory, especially the application of non-optimized design of the flip classroom teaching mode, in such teaching is not even as traditional teaching. And, for large classes of courses are not suitable for flip classroom mode [12]. Therefore, as a college educator, remember not to blindly follow, thus losing the essence of quality education. Second, increase the awareness of the requirements for students. Flip the classroom requires students to self-learning form, according to the teacher produced by the teaching video to complete the knowledge to build. Students in this learning model, play a conscious to watch the teacher to provide teaching video, which can really allow students to learn from the relevant knowledge points. However, from the current development of China's institutions of higher learning, most of its students are long-term impact by traditional education. And more students dependent on the passive acceptance of the learning model to learn. Students 'consciousness needs to be further strengthened, which requires parents and teachers in a timely manner to promote the awareness of improving students' learning [13].Third, further enhance the professional competence of teachers. Flip the classroom application process, the need to rely on multimedia to network technology to achieve. Therefore, the quality of education staff, must master the network communication technology, skilled operation of the computer, intelligent terminal technology and other related equipment, to be able to give students a better guide to improve the efficiency of the classroom teaching mode. In addition, because the multimedia technology is to flip the presentation of the foundation, to achieve the perfect display, we must have superb production technology. Through the master of these technologies can be educational content and multimedia technology integration, and ultimately achieve the effect of human-computer interaction. Fourth, establish a scientific, long-term flip classroom teaching evaluation mechanism. At present, the study of the development and evaluation of the classroom is still in the initial stage. It is necessary to set up a teaching and research team to flip the classroom and to turn the classroom supervisory group. Under the guidance of the steering group, the classroom teaching design should be carried out to carry out the effective teaching of the classroom. Micro-course, improve the quality of micro-courses. Members of the supervisory team should have technicians, media consultants, visual experts and other personnel, in order to truly flip the classroom teaching to guide and reasonable supervision for the teaching of the classroom to provide theoretical support [14].

In short, the relationship between flip classroom and traditional teaching is not simple "Dongfeng overwhelming westerly", flip classroom teaching model has its advantages, the traditional teaching is not means nothing. Flip classroom teaching mode and traditional teaching should coexist, even if the same course of teaching should also be combined with the two. The teaching mode of college teaching is helpful to make up for the deficiency of traditional teaching. It should actively create favorable conditions for the implementation of the classroom teaching mode, and provide strong guarantee for the promotion of quality education.

\section{References}

[1] Graham. R. Commentary: The Khan Academy and the Day-Night Flipped Classroom [J].Biochemistry. And Molecular Biology Educa-tion, Vol.40(2012)No.5,P.337-338.

[2] F. Lu. Promoting Curriculum Sharing and Teaching Reform to Improve Teaching Quality in Universities [J].Chinese University Teaching, 2014, No. 1,P.8-11(in Chinese) 
[3] Y. Huang, L. Jiang and L. Huang. The Application of Reversing Classroom in Experimental Teaching of Modern Educational Technology [J].China's Audio- visual Education, 2014, No.4, P. 20-25.(in Chinese)

[4] J.L. Zhang, Y. Wang, and B. H. Zhang. Research on the Teaching Mode of Translating Classroom [J]. Journal of Distance Education, 2012, No.4, P.46-51 (in Chinese)

[5] B. CH. Pan. An Experimental Study on the Application of Inverted Classroom Model in College Teaching [J] Research on Electrification Teaching.2015,No.3, P.83-88(in Chinese)

[6] Liu P. Application of flipped classroom in vocational practice teaching of pathogenic biology and immunology[J].China Medical Education Technology,Vol.29(2015)No.1,P.59-62(in Chinese)

[7] X. Long. An Empirical Study on the Application of "Reversing Classroom" to Information Literacy Education[J].Journal of Academic Libraries,2014,No.6, P.97-102 (in Chinese)

[8] Y. Li and L. L. Zhu. Analysis and Reflection on the Effect of Teaching in Higher Education [J].Research on Electrification Education,2016, No.2, P.82-87 (in Chinese)

[9] Q. Lu. Reflections on the Translation of Classroom: Demonstration and Reflection [J].Research on Electrification Education, 2013, No.8,P.21 (in Chinese)

[10]J. Guo. Flip the classroom: the problems of Sino - US educational environment [J].Information Technology Education in Primary and Secondary Schools,2014,No.1,P.72-76(in Chinese)

[11]Y. Li. Rational Thinking on China's Flip in Classroom [J].Curriculum. Teaching Materials. Teaching method, Vol.34(2014) No. 10, P18-23 (in Chinese)

[12]M. J.Xia. A Study on the Application of Inverted Classroom Teaching Mode in Yunnan Borderland Colleges and Universities [J].Modern Educational Technology,2017,No.2,P.7 (in Chinese)

[13]A.X. Xu. Research on the Application of Reversing Classroom in Quality Education in Higher Vocational Education [J]. Management Manager,2016,No.12,P.488 (in Chinese)

[14]M.J. Liao and Q. Wang. Interchange of Classroom in Colleges and Universities: Current Situation, Effect and Challenge [J].Open Education Research,Vol.21(2015)No.5,P.74-82 (in Chinese) 